\title{
Darier Disease
}

National Cancer Institute

\section{Source}

National Cancer Institute. Darier Disease. NCI Thesaurus. Code C84665.

An autosomal dominant inherited chronic skin disorder caused by mutations in the ATP2A2 gene. It is characterized by the development of yellow-brown keratotic skin papules in the neck, ears, forehead, chest, back and groin. It is associated with frag ility of the free margins of the nails. 